\title{
Spatial Distribution of SoIl Loss in UpPER Didessa Watershed, Ethiopia
}

\section{FAYERA GUdU TUFA ${ }^{1 *}$ AND TOLERA ABDisSA FEYISSA ${ }^{1}$}

1 Jimma University, Faculty of Civil and Environmental Engineering, Department of Hydraulic and Water Resources Engineering, Jimma, Ethiopia

* Corresponding author, fayerag2@gmail.com

Received on 23 November 2019

Received in revised form on 12 December 2019

Accepted on 13 December 2019

Editor: Maria Virginia Alves Martins, Universidade do Estado do Rio de Janeiro, Brazil

\section{Abstract}

Soil erosion is dramatically increasing and accelerating in developing countries like Ethiopia. It has worrisome economic and environmental impacts and causes nutrient loss on agricultural land, sedimentation in rivers and reservoirs, clogged canals and other water supply systems. Determination of spatial distribution of soil loss rate in upper Didessa watershed is an important priority for prioritizing the area for watershed management practices in order to reduce soil erosion. The Revised Universal Soil Loss Equation (RUSLE) framed with geographical information system and remote sensing technique was used to estimate the mean annual soil loss in Upper Didessa Watershed, Ethiopia. Digital elevation model (DEM) with

\section{Introduction}

With the acceleration of agricultural expansion in Ethiopia, the rate of soil erosion has been changing. The rate of soil loss is varying with time and space due to different factors. Hurni reported that Ethiopia loses 1.3 billion metric tons of fertile soils every year (Hurni, 1988) and McColl reported that this country loses 1.9 billion metric tons of fertile soil every year (McColl and Aggett, 2007). The soil erosion as a function of water spatial variation ranges from 16 to 300 ton per ha per year in Ethiopia (Tesfaye et al., 2014). Balthazar reported that the rate of soil erosion in Blue Nile river basin shows considerable spatial variation from 4 to 4935 ton per square kilometer per year (Balthazar et al., 2012). This variation resulted from variation in land cover, soil characteristics, land slope, rainfall, temperature and life stock density (Awulachew et al., 2010).

Even though, Ethiopian government is applying soil and water conservation strategies in various part of the country, agricultural expansion which accelerates soil erosion is continued due to population growth. Soil erosion is remaining a serious threat to the country and needs attention of researchers. More than 200 researches have
Citation:

Tufa, F.G. Feyissa, T.A., 2019. Spatial Distribution of Soil Loss in Upper Didessa Watershed, Ethiopia. Journal of Sedimentary Environments, 4 (4): 434-443.

$30 \mathrm{~m} \times 30 \mathrm{~m}$ resolution was collected from Ministry of Water, Irrigation and Energy and used to delineate the watershed. Soil loss factors of the watershed like length and slope factor (LS), soil erodibility factor $(\mathrm{K})$, cover management factor $(\mathrm{C})$, support practicing factor $(\mathrm{P})$ and rain fall erosivity factor $(\mathrm{R})$ were evaluated and integrated in GIS to compute the annual soil loss rate of the watershed. The results of this work reveal that the annual rate of soil loss in the watershed is $5.23 \mathrm{t} / \mathrm{ha} /$ year. They also show that the central part of the watershed is an area prone to soil erosion.

Keywords: GIS. Soil loss. RUSLE. Upper Didessa watershed.

been conducted on soil erosion, and soil and water conservation in Ethiopia. However, most of them were focused on the Ethiopian highlands mainly in the northern Ethiopian highlands (Haregeweyn et al., 2015). The eastern, western and southern parts of the country need attention of researchers. Upper Didessa sub-basin is located in southwestern part of the country which is less studied area. However various water resource projects are being under construction. For example: Arjo Didessa dam which has been constructed for irrigation and hydropower is subjected to silting generated from upper Didessa watershed.

Numerous models are available to study soil erosion and the most widely used in different parts of the world are: Soil and Water Assessment Tool (SWAT) (Srinivasan et al., 1998), Erosion Productivity Impact Calculator (EPIC) (Kiniry et al., 1995), Chemicals, Runoff, Erosion from Agricultural Management Systems (CREAMS) (Knisel, 1980), Agricultural Non-point Source Pollution Model (AGNPS) (Young et al., 1989), Areal Nonpoint Source Watershed Environmental Response Simulation (ANSWERS) (Beasley et al., 1982), EROSION-3D (Schmidt et al., 1999), Water Erosion Prediction Project 
(WEPP) (Laflen et al., 1991), European Soil Erosion Model (EUROSEM) (Morgan et al., 1998) and GIS-based Revised Universal Soil Loss Equation (RUSLE) (Renard et al., 1997).

Geographic Information System (GIS) and remote sensing technique has become an important tool in the spatial analysis of factors such as topography, soil and land use/land cover. GIS based RUSLE method was used in Didessa watershed to predict sediment yield (Tukura \& Akalu, 2019). GIS provides a digital representation of the catchment, which can be used in hydrologic modelling. The land surface slope, land use and soil characteristics can be extracted using this technique. In the current study, the parameters of soil erosion were generated by GIS (Jain et al., 2001). The Universal Soil Loss Equation (USLE) (Wischmeier and Smith, 1965) is designed to predict soil loss from sheet and rill erosion in specific conditions from agriculture fields and later improved to Revised Universal Soil Loss Equation (RUSLE) (Renard et al., 1997). Runoff factor $(\mathrm{R})$, which accounts erosivity potential of rain fall

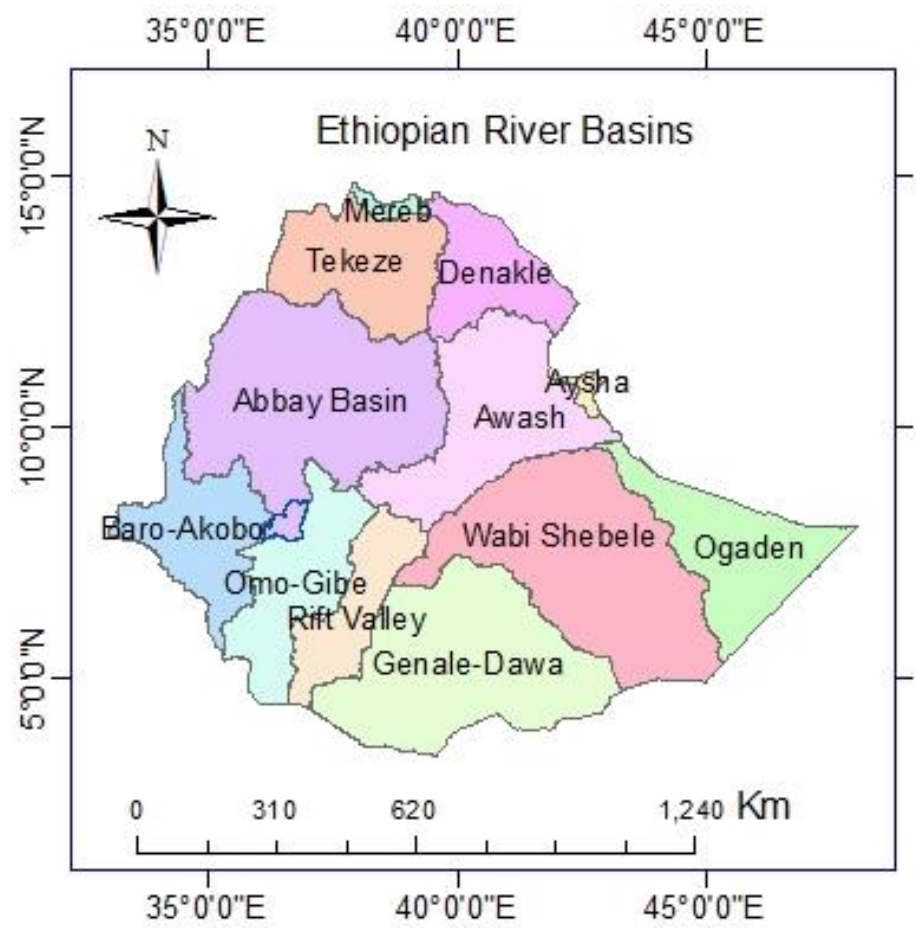

Fig. 1. Location of study area.

\subsection{Data collection and Analysis}

In this study, soil loss modelling was employed by using RUSLE empirical equation integrated in GIS environment. Topographic map (high resolution) of the study area was collected from Ministry of Water, Irrigation and Energy of Ethiopia (MoWIE), then scanned, georeferenced, and converted to WGS84, zone $37^{\circ} \mathrm{N}$ projection system using ArcGIS software and the associated packages. The catchment was demarcated using topographic sheets and
RESEARCH PAPER

droplet and runoff has been incorporated in RUSLE for soil loss rate estimation. The objective of this research was to determine the spatial distribution of soil loss in Upper Didessa watershed and to estimate the annual soil loss rate from the watershed by using GIS based RUSLE.

\section{Methods and materials}

\subsection{Location of study area}

Upper Didessa watershed is located in the south-western part of Ethiopia. Upper Didessa watershed has drainage area of $5071.132 \mathrm{~km}^{2}$. It is part of Didessa sub-basin and geographically located between $36^{\circ} 5^{\prime} 0^{\prime \prime}$ and $37^{\circ} 0^{\prime} 0^{\prime \prime} \mathrm{E}$ longitude, and between 7040'0" and 8035'0" N latitude. The altitude in upper Didessa watershed ranges between 1269 and 3031 meters above sea level, elevation (m.a.s.l.). The highlands in the south-western and south-eastern parts of the basin are higher in altitude than 2000 m.a.s.l. Location map of upper Didessa watershed is shown in figure 1.

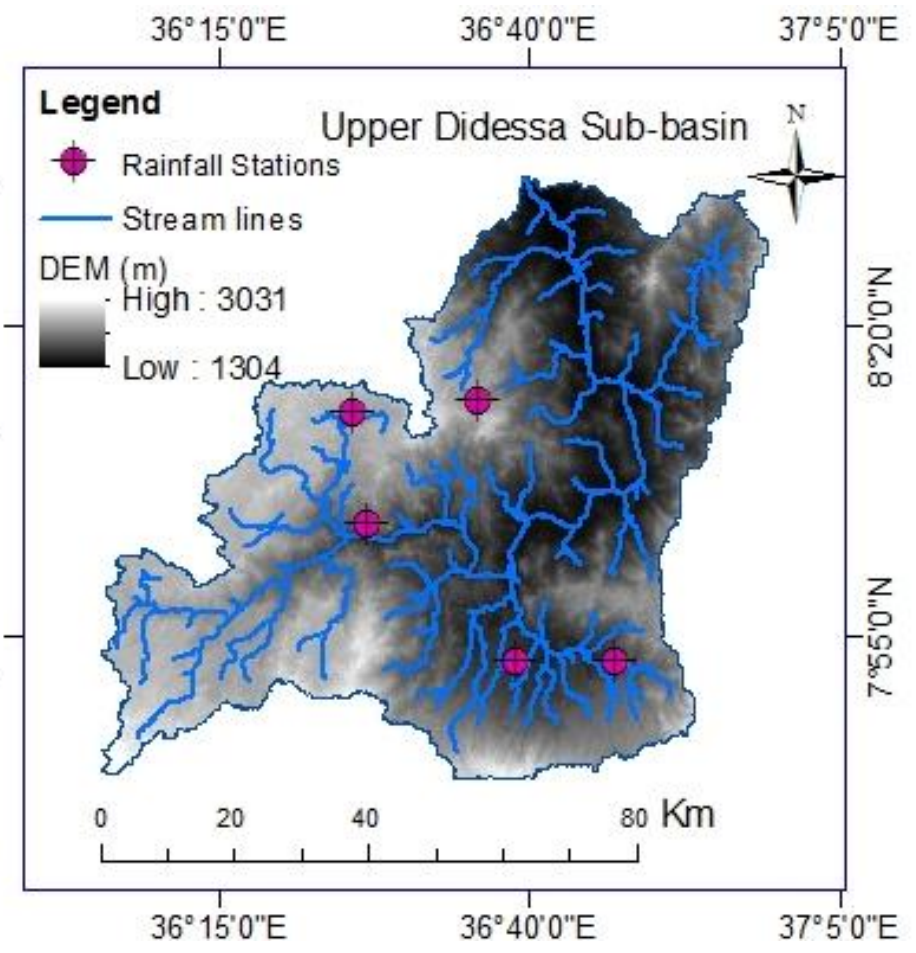

DEM of $30 \mathrm{mX} 30 \mathrm{~m}$ resolution. Slope categories and elevation zones were also derived from the DEM.

Grid based (cell by cell) soil loss rate of the watershed was predicted by using revised universal soil loss equation (RUSLE) in GIS environment (Angima et al., 2003). Thus, grid cells were determined before the calculation of the physical characteristics of these cells such as: slope, land use and soil type, all of which affect soil erosion process in different grids of the watershed. The average annual soil 
erosion rate $(\mathrm{A})$ in tons per hectare per year was determined by using empirical equation (RUSLE) (Renard et al., 1997) as expressed in equation 1:

\section{$A=R * K * L S * C * P$}

Where: A indicates the average annual soil loss due to water erosion (ton per ha per year); $\mathrm{R}$ is the rainfall-runoff erosivity factor; $\mathrm{K}$ is the soil erodibility factor; LS is the slope length and slope steepness factor; $\mathrm{C}$ is the cover management practice factor; $\mathrm{P}$ is the conservation support, or erosion control practices factor.

\subsubsection{Rainfall Erosivity (R) factor}

To generate a soil loss map, rainfall data for calculation of rainfall erosivity (R) was collected from ministry of Water, Irrigation and Energy. The mean annual rainfall data of five stations were used to compute rainfall erosivity factor (R). Rainfall erosivity (R) is a term used to describe the susceptibility of the soil to wash off the disturbed and de-vegetated areas into surface waters of the state during storms (Shiferaw, 2012). Different approaches can be used to derive R. In this study, empirical equation developed for Ethiopia and Egypt was used (Hurni, 1985).

$R=0.55 M A P-24.7$

Where $\mathrm{R}$ is the rainfall erosivity factor and MAP is the mean annual rainfall $(\mathrm{mm})$.

\subsubsection{Soil Erodibility $(\mathbf{K})$ factor}

Soil data, maps of soil units and associated information was obtained from Ministry of Water, Irrigation and Energy. The erodibility of soil is a tendency of particle of

$$
L S=\operatorname{power}\left((F A C) *\left(\frac{\text { cell size }}{22.1}\right), 0.4\right) * \operatorname{power}\left(\frac{\sin ((\text { slope }) * 0.01745)}{0.09,1.4}\right) * 1.4
$$

Where, FAC - Flow Accumulation (a raster-based on total of the accumulated flow to each cell) Cell size - length and width of pixel side (size of each pixels)

Slope - Slope steepness

\subsubsection{Land cover management factor $(\mathrm{C})$}

The land cover management factor $(C)$ reflects the effect of cropping and other management practices on erosion rates. It determines the relative effectiveness of soil and land cover management systems in controlling soil erosion (Kaltenrieder, 2007). Vegetation cover is a significant factor to control soil erosion rate (Esa et al., 2018). The land cover determines the portion of rainfall that infiltrates into the soil and converted into surface runoff, which is a driving force for soil erosion. Researchers assigned $\mathrm{C}$ factor value for different land use/land covers. The land use/land cover satellite image was downloaded from satellite website database (https://earthexplorer.usgs.gov) and reclassified by using digital image processing software, earth resource development assessment system (ERDAS). The data layer was extracted for $C$ factor of the RUSLE model. $C$ factor values were taken from literature. In this case, $\mathrm{C}$ factor was
RESEARCH PAPER

soil to detach from parent materials and transport by rainfall. It is determined by the cohesive force between the soil particles, which may vary depending on the presence or absence of plant cover, soil moisture content, and development of its structure (Wischmeier and Smith, 1978). $\mathrm{K}$ values of different soil type were obtained from literature and used in the present study.

\subsubsection{Slope length-steepness (LS) factor}

LS factor is the combination of two factors. The first one is slope steepness factor ( $\mathrm{S}$ sub-factor), which influences the flow velocity and hence the rate of soil erosion. The second factor is slope length factor ( $\mathrm{L}$ subfactor) which describes the distance between the origin and termination of inter-rill processes (Wischmeier and Smith, 1978). The termination of inter-rill processes is the point where the depositional process begins due change in slope or constructed conservation practices.

LS factor was determined from watershed slope that was derived by GIS and flow accumulation generated by ArcHydro software. In RUSLE, the LS-factor represents a ratio of soil loss under given conditions to that at an area with the slope steepness of $9 \%$ and slope length of $22 \mathrm{~m}$ (Kaltenrieder, 2007). The steeper and longer the slope, the higher is the force to generate soil erosion. In the present study, the equation developed by (Moore and Burch, 1986) was employed. ArcGIS raster calculator was used to compute LS factor by using map algebra expression described in equation 3 . 
In the present study, $\mathrm{P}$ factor value of 1 was adopted for non-agricultural areas, where there are no support practices, and it depends on the slope and type the crop for agricultural land.
RESEARCH PAPER

Contour farming is used as support practice in the upper Didessa watershed. Generally, all the procedures and processes followed in the present study are shown in figure 2.

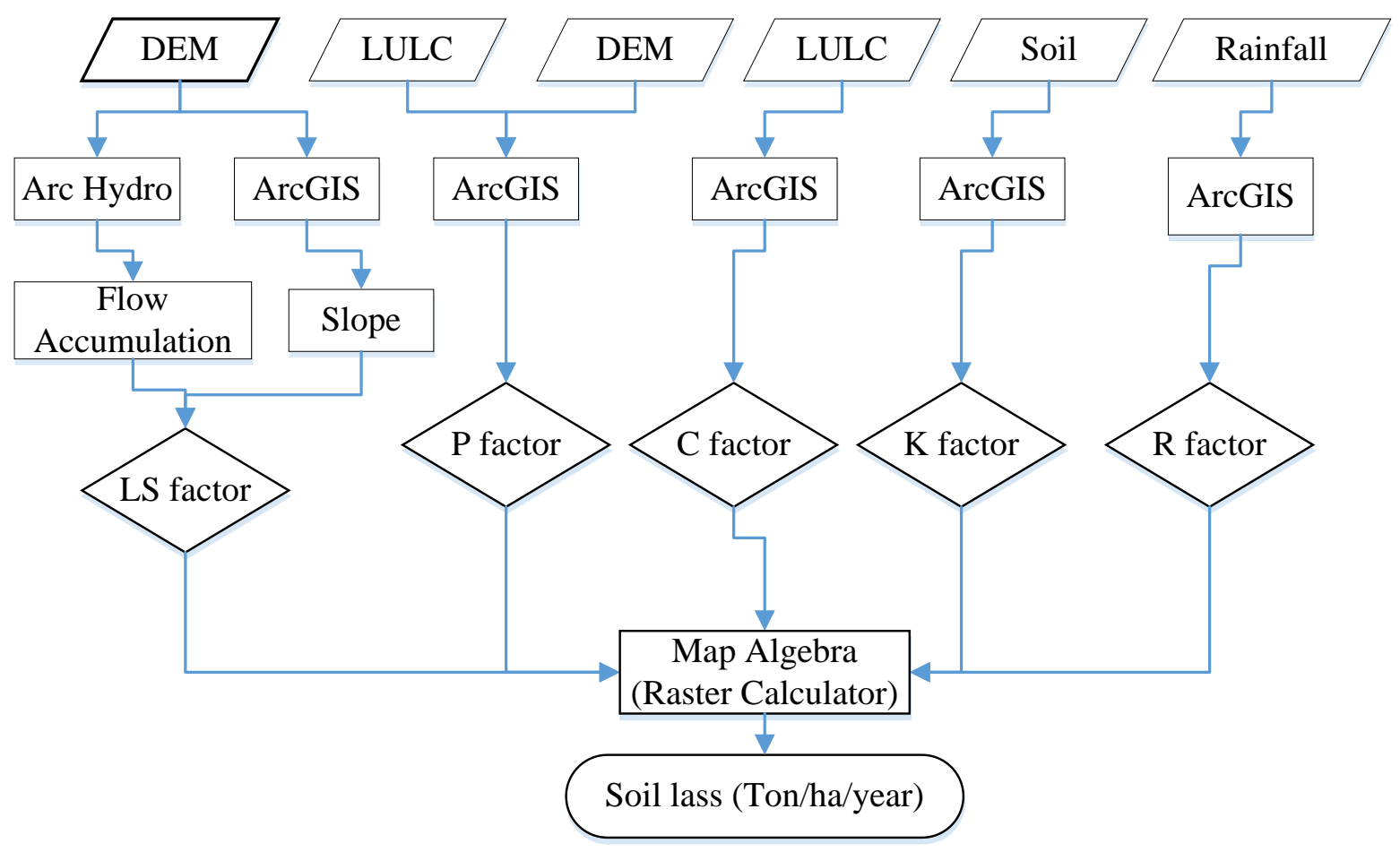

Fig. 2. Flow chart for determination of soil loss.

\section{Results and discussion}

\subsection{Soil loss factors}

\subsubsection{Estimated $\mathbf{R}$ factor}

Annual rainfall data of five stations were used for determination of rain fall erosivity $(\mathrm{R})$ factor. The value of $\mathrm{R}$ is greatly varying with location and ranges between 1156.81 and 1000.62 for the present study area as shown in figure 3. The north-western part of the study area is characterized by high rainfall erosivity factor whereas the south-eastern part is characterized by relatively low erosivity factor.

\subsubsection{Estimated $\mathrm{K}$ factor}

Soil erodibility $(K)$ factor vary with the susceptibility of the soil to erosion. The present study area comprise five major soil types as described in table 1 and erodibility factor $(K)$ for each soil type were assigned as shown in figure 4 . The values of $\mathrm{K}$ factor for different soil type were obtained from literature (Esa et al., 2018). The southern most part, north-eastern and north-western part are characterized by high erodibility factor which indicates that the soil has less resistivity to soil erosion. The soil has low cohesiveness. Most part of the study area has medium erodibility factor, especially at the southern part. Following the main stream, the $\mathrm{K}$ value is low which represents highly structured and stable soil. Soil erodibility factor map of the watershed is shown in figure 4.

\subsubsection{Estimated slope LS factor}

The effects of slope length and slope steepness on erosion are measured in terms of LS factor. In the present study, the value of LS varies between 0 and 84.89. The value of LS for most part of the watershed ranges from low to moderate as shown in figure 5 .

\subsubsection{Estimated C factor}

The C-factors are the most important values for crop management and other types of land cover. The land cover satellite image was downloaded from satellite and reclassified by using ERDAS software. The reclassified LULC map and corresponding $C$ factor values for the study area are described in table 2 and shown in figure 6. Different references have been reviewed to assign $C$ factors for different types of land cover (Esa et al., 2018). The middle part of the watershed, from north to south was dominantly cultivated which is characterized by high 
$C$ factor and the downstream part was covered by forest which is represented by low $\mathrm{C}$ factor.

\subsubsection{Estimated P Factor}

Conservation/support practices dominantly affect erosion by changing the flow pattern, grade, direction of runoff and the rate of runoff. The conservation/support
RESEARCH PAPER

practices consider strip-cropping, terracing, contouring and sub-surface drainage (Renard et al., 1997).

In the present study, for the preparation of $\mathrm{P}$ factor map, the land use/land cover map and land slope map were used. For non-agricultural land $\mathrm{C}$ factor was assumed to be 1 and for agricultural land $\mathrm{C}$ factor ranges from 0.15 to 0.22 as described in table 2. Raster map of $\mathrm{C}$ factor is shown in figure 7 .

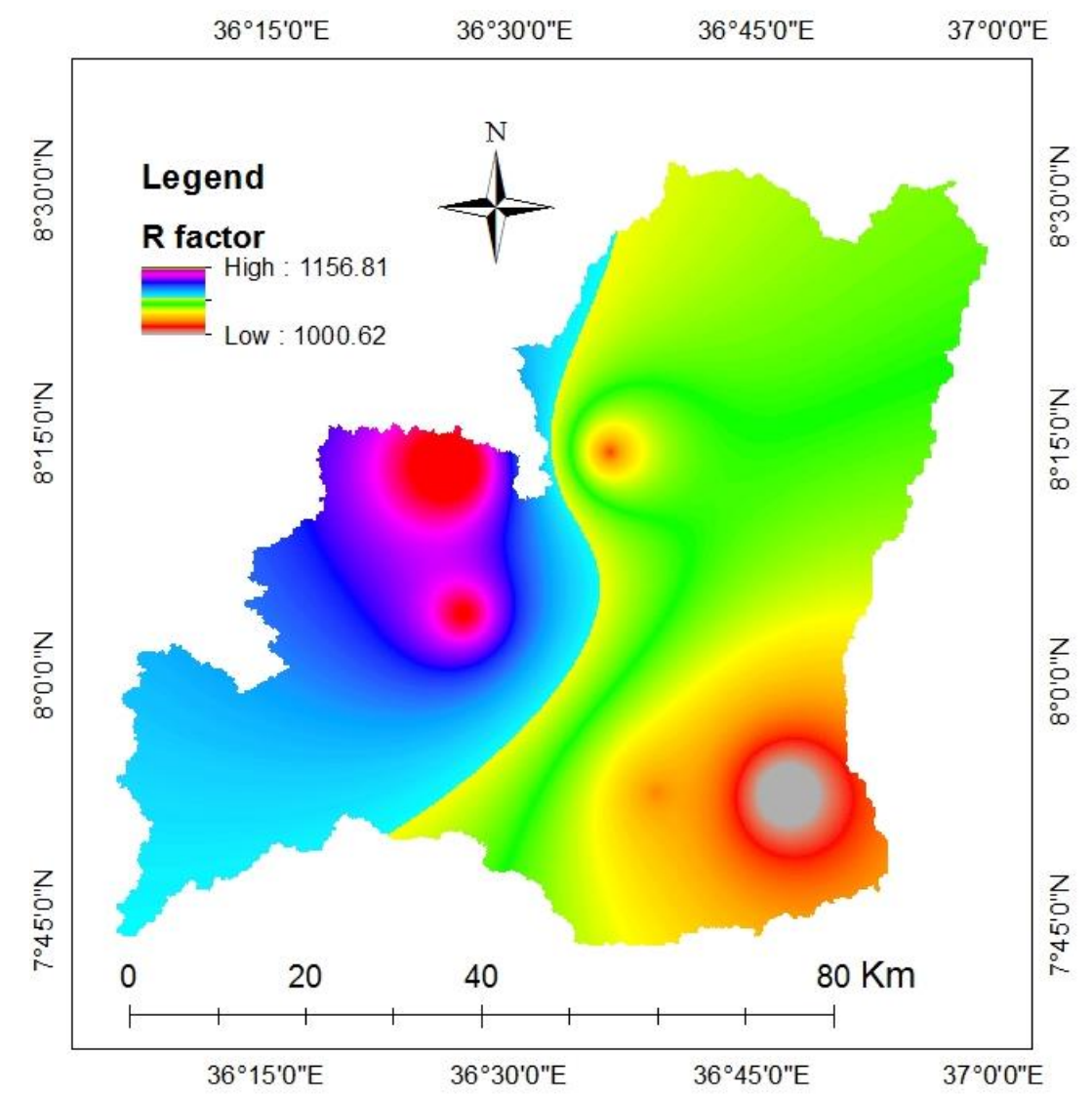

Fig. 3. Rainfall erosivity (R) factor.

Tab. 1. Values of $\mathrm{K}$ factors for different types of soil.

\begin{tabular}{c|l|c|c|}
$\boldsymbol{N}^{\boldsymbol{o}}$ & \multicolumn{1}{|c|}{ Soil type } & \multicolumn{1}{c|}{ Area $\left(\mathbf{K m}^{\mathbf{2}} \mathbf{)}\right.$} & K factor \\
\hline 1 & Eutric Vertisols & 1504.56 & 0.15 \\
\hline 2 & Haplic Nitosols & 548.42 & 0.25 \\
\hline 3 & Haplic Alisols & 1291.59 & 0.20 \\
\hline 4 & Haplic Acrisols & 186.63 & 0.30 \\
\hline 5 & Rhodic Nitosols & 105.63 & 0.25 \\
\hline
\end{tabular}




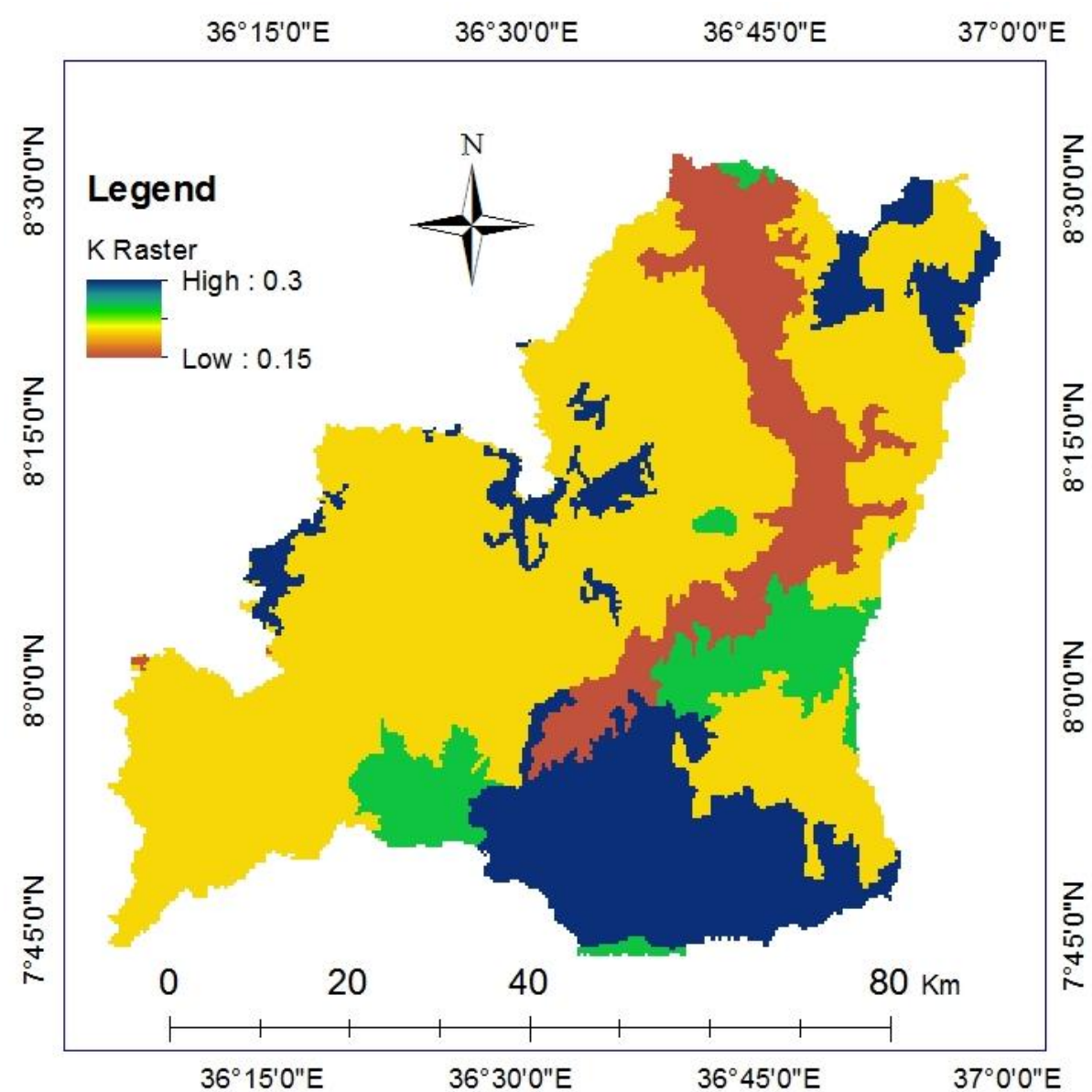

Fig. 4. Soil erodibility (K) factor

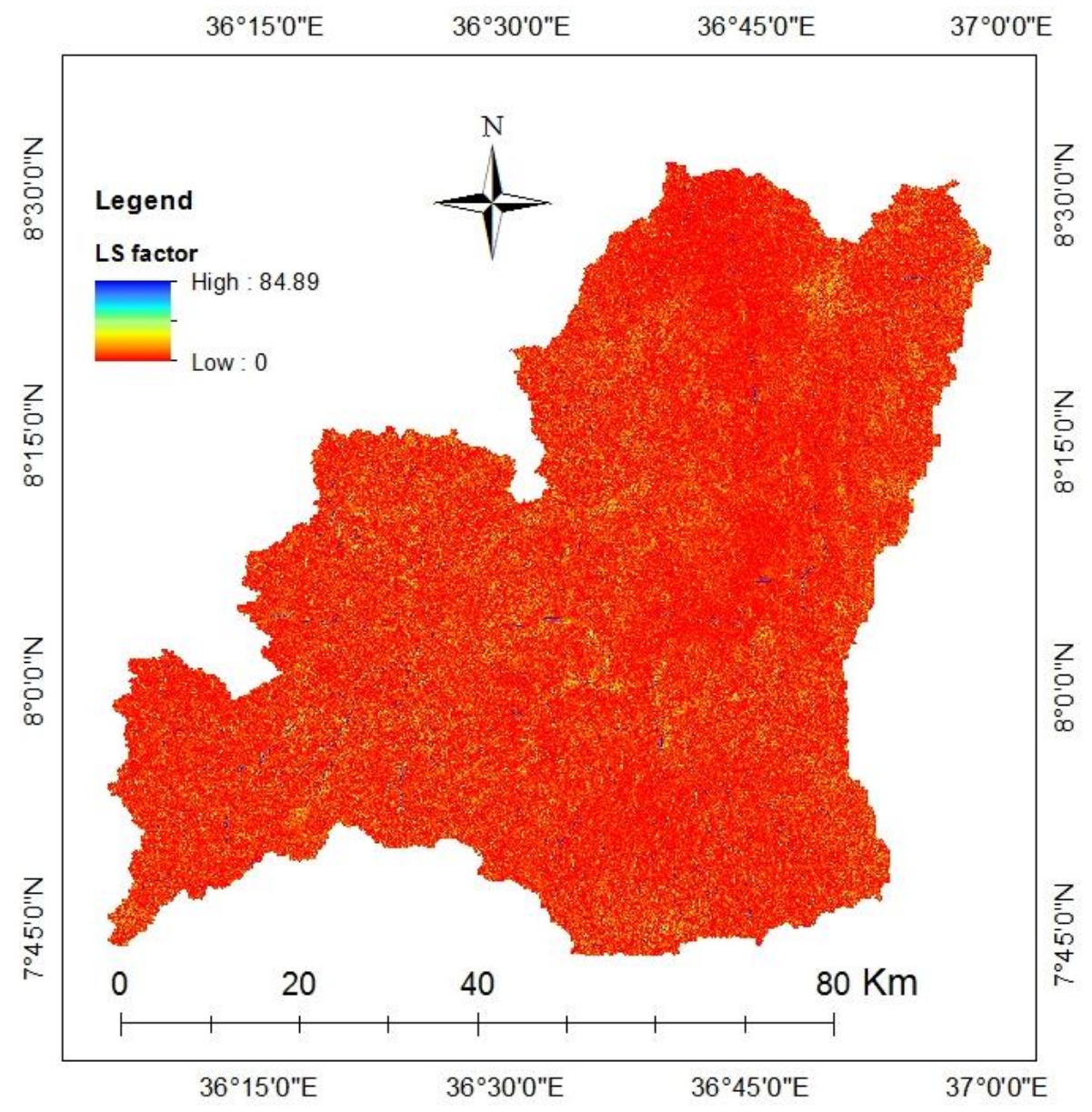

Fig. 5. Slope length and steepness (LS) factor. 

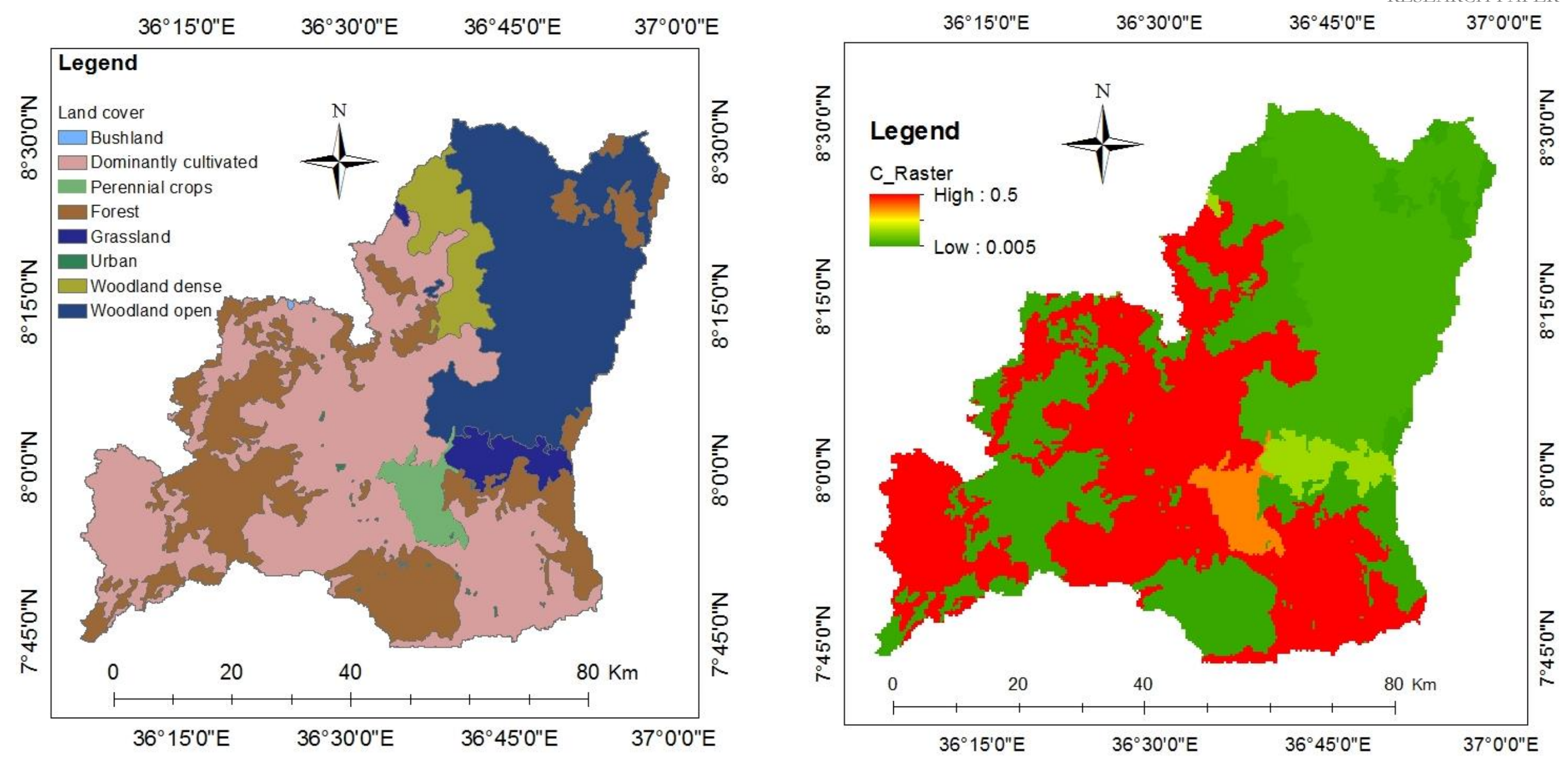

Fig. 6. Land use/land cover map and corresponding C factor values. 
Tab. 2. Value of $\mathrm{C}$ factor and $\mathrm{P}$ factor for land use land cover type.

\begin{tabular}{|c|l|c|c|c|}
\hline $\mathbf{N}^{\mathbf{0}}$ & Landcover & Area $\mathbf{( K m}^{\mathbf{2}} \mathbf{)}$ & $\mathbf{C}$ factor & P factor \\
\hline $\mathbf{1}$ & Woodland open & 2505.97 & 0.03 & 1 \\
\hline $\mathbf{2}$ & Grassland & 383.51 & 0.15 & 1 \\
\hline $\mathbf{3}$ & Woodland dense & 385.16 & 0.008 & 1 \\
\hline $\mathbf{4}$ & Forest & 26.61 & 0.005 & 1 \\
\hline $\mathbf{5}$ & Dominantly cultivated & 173.60 & 0.50 & 0.15 \\
\hline $\mathbf{6}$ & Bushland & 38.17 & 0.05 & 1 \\
\hline $\mathbf{7}$ & Urban & 0.32 & 0.01 & 0.15 \\
\hline $\mathbf{8}$ & Perennial crops & 123.51 & 0.37 & 0.22 \\
\hline
\end{tabular}

\subsection{Estimated soil loss rate}

The land use, soil, slope steepness, slope length and cover management practices parameters are the main factors governing soil erosion potential at particular location to the erosive power of rainfall. Maps for values of the RUSLE parameters R, K, LS, C and P factors were integrated in ArcGIS using map algebra (raster calculator) to form composite map of terms soil erosion. The map of composite factors represents soil erosion potential of different grid cells. High values of this term indicate a higher potential of soil erosion in the cell and vice-versa. Figure 8 shows the areas of varying soil loss rate values (ton/ha/year) and hence the soil erosion potential in the different cells of the upper Didessa watershed. The information shown in Figure 8 could be utilized for identification of the soil erosion prone areas of the watershed. The watershed has been classified on the basis of administrative region for the purpose of watershed management practices (Esa et al., 2018, Asmamaw and Mohammed, 2019) classified soil rate as very low $(0-5$ ton/ha/year), low (5-15 ton/ha/year), moderate (15-30 ton/ha/year), high (30-50 ton/ha/year) and very high $(>50$ ton/ha/year).

Based on this classification, most part of the study area were experiencing very low to low soil loss rate. However, soil loss rate generated from the central and southeastern part of the watershed exceeds 50 ton/ha/year and needs immediate intervention. Particularly, Kersa, Mana, Goma, Dedessa and some parts of Gechi and Limu Kosa need watershed management practices (Fig. 8). The average annual soil loss rate generated from Upper Didessa watershed was estimated at 5.23 ton/ha/year.

The Arjo Didessa Dam is located downstream of the river basin. Therefore, public authorities should take river basin management measures to reduce sediment production in order to increase the efficiency of the dam.

\section{Conclusion}

GIS and remote sensing technique are the most important tools for determination of soil erosion rate, especially in watershed with no record of sediment data, like at upper Didessa. In the present study, GIS and remote sensing techniques were employed to determine soil loss rate of the watershed. Soil loss rate from most of the area of the watershed could be classified as having low soil erosion rate. The bulk erosion rate was 5.23 ton/ha/year, which can be considered a low soil loss rate, since most part of the watershed is covered by forest. However, soil erosion protection methods should be applied to the middle part of the watershed where high soil loss rate was observed since this watershed drains to Arjo Didessa dam.

\section{Acknowledgements}

The Authors acknowledge Ethiopian Ministry of Water, Irrigation and Energy for their contribution in providing required data for this research.

\section{References}

Adugna, A., Abegaz, A., Cerda, A.,2015. Soil erosion assessment and control in Northeast Wollega, Ethiopia. Solid Earth Discussions, 7. https://doi.org/10.5194/sed-7-3511-2015

Angima, S., Stott, D., Neill, M., Ong, C., Weesies, G., 2003. Soil erosion prediction using RUSLE for central Kenyan highland conditions. Agriculture, ecosystems \& environment, 97, 295308.

Asmamaw, L.B., Mohammed, A.A., 2019. Identification of soil erosion hotspot areas for sustainable land management in the Gerado catchment, North-eastern Ethiopia. Remote Sensing Applications: Society and Environment, 13, 306-317.

Awulachew, S. B., Ahmed, A., Haileselassie, A., Yilma, A. D., Bashar, K., Mccartney, M. P., Steenhuis, T., 2010. Improved water and land management in the Ethiopian highlands and its impact on downstream stakeholders dependent on the Blue Nile. 


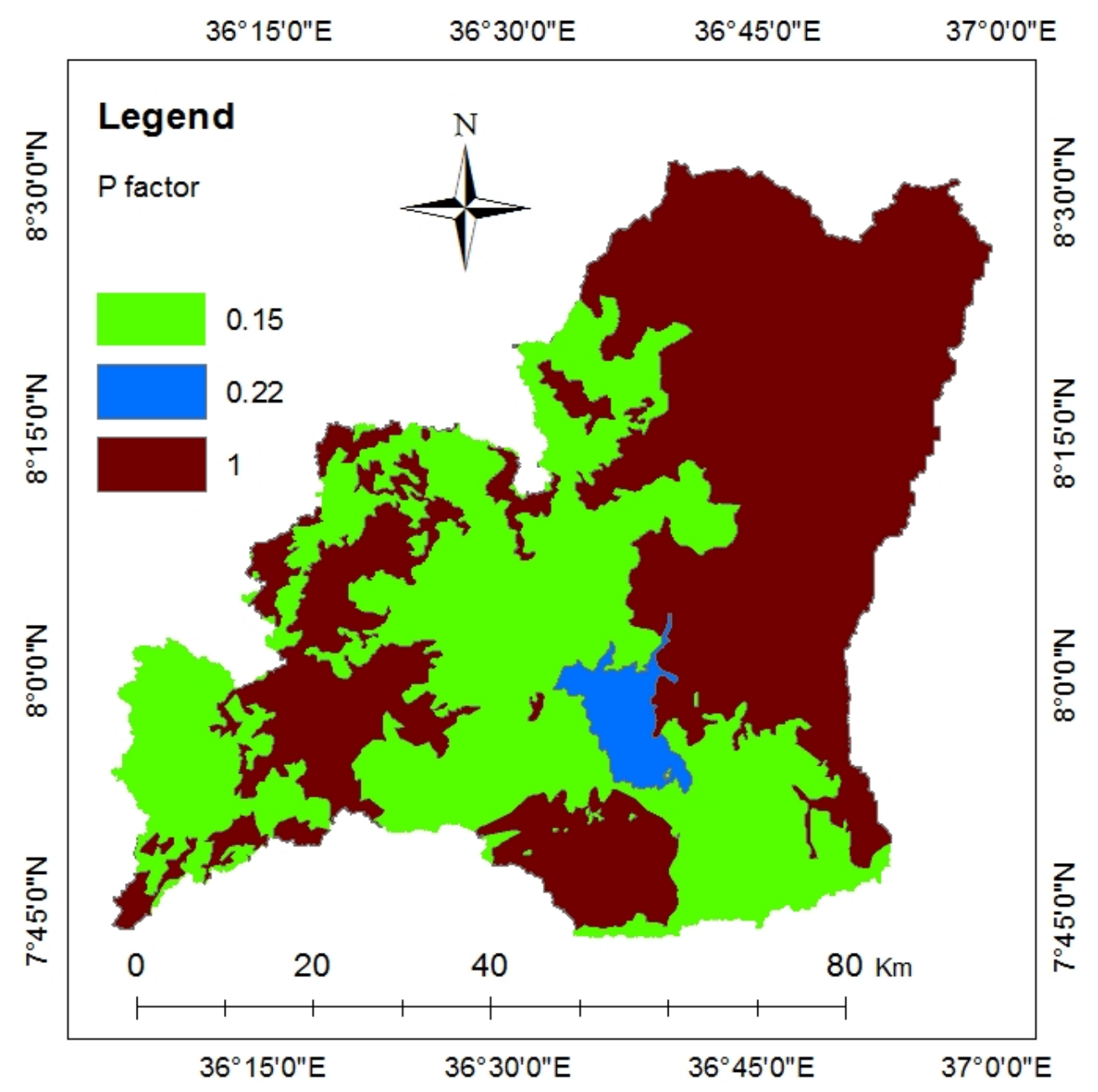

Fig. 7. Conservation practicing $(\mathrm{P})$ factor.

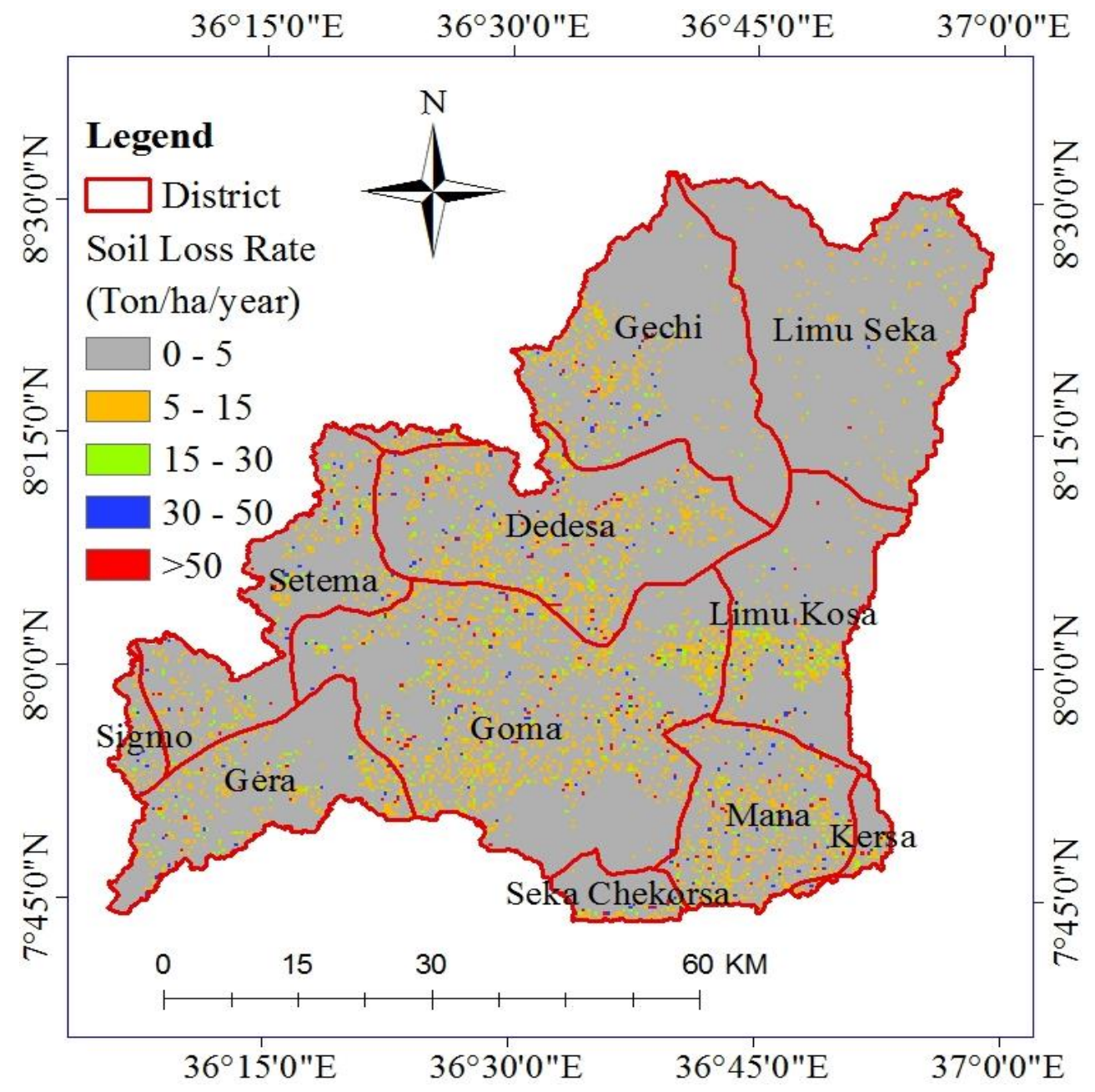

Fig. 8. Spatial distribution of soil loss map. 
Balthazar, V., Vanacker, V., Girma, A., Poesen, J., Golla, S., 2012. Human impact on sediment fluxes within the Blue Nile and Atbara River basins. Geomorphology, 180, 231 241.

Beasley, D. B., Huggins, L. F., Monke, E., 1982. Modeling sediment yields from agricultural watersheds. Journal of Soil and Water Conservation, 37, 113-117.

Esa, E., Assen, M., Legass, A., 2018. Implications of land use/cover dynamics on soil erosion potential of agricultural watershed, northwestern highlands of Ethiopia. Environmental Systems Research, 7, 21. https:/ /doi.org/10.1186/s40068-018-0122

Haregeweyn, N., Tsunekawa, A., Nyssen, J., Poesen, J., Tsubo, M., Tsegaye Meshesha, D., Schatt, B., Adgo, E., Tegegne, F., 2015. Soil erosion and conservation in Ethiopia: a review. Progress in Physical Geography, 39, 750-774. https://doi.org/10.1177/0309133315598725

Hurni, H., 1985. Erosion-productivity-conservation systems in Ethiopia. https://doi.org/10.7892/boris. 77547

Hurni, H., 1988. Degradation and conservation of the resources in the Ethiopian highlands. Mountain research and development, 123-130. https:/ /doi.org/10.2307/3673438

Jain, S. K., Kumar, S., Varghese, J., 2001. Estimation of soil erosion for a Himalayan watershed using GIS technique. Water Resources Management, 15, 41-54. https://doi.org/10.1023/A:1012246029263

Kaltenrieder, J., 2007. Adaptation and validation of the universal soil loss equation (USLE) for the EthiopianEritrean Highlands. Unpublished thesis. University of Bern, Switzerland.

Kiniry, J. R., Williams, J. R., Major, D., Izaurralde, R., Gassman, P. W., Morrison, M., Bergentine, R., Zentner, R., 1995. EPIC model parameters for cereal, oilseed, and forage crops in the northern Great Plains region. Canadian Journal of Plant Science, 75, 679-688.

Knisel, W. G., 1980. CREAMS: a field scale model for Chemicals, Runoff, and Erosion from Agricultural Management Systems [USA]. United States. Dept. of Agriculture. Conservation research report (USA).

Laflen, J.M., Lane, L.J., Foster, G.R., 1991. WEPP: A new generation of erosion prediction technology. Journal of Soil and Water Conservation, 46, 34-38.

McColl, C., Aggett, G., 2007. Land-use forecasting and hydrologic model integration for improved land-use decision support. Journal of environmental management, 84, 494-512. https://doi.org/10.1016/j.jenvman.2006.06.023

Moore, I. D., Burch, G. J., 1986. Physical basis of the lengthslope factor in the universal soil loss equation 1. Soil Science Society of America Journal, 50, 1294-1298.
RESEARCH PAPER

Morgan, R., Quinton, J., Smith, R., Govers, G., Poesen, J., Auerswald, K., Chisci, G., Torri, D. \& Styczen, M., 1998. The European Soil Erosion Model (EUROSEM): a dynamic approach for predicting sediment transport from fields and small catchments. Earth Surface Processes and Landforms: The Journal of the British Geomorphological Group, 23, 527-544.

Tukura, N.T., Akalu, M.M., 2019. Soil Erosion Risk Assessment Due to Land Use/Land Cover Changes (LULC) in Hangar River Watershed, Northwest Ethiopia. Journal of Sedimentary Environments, 4, 379386. https://doi.org/10.12957/jse.2019.46538

Renard, K. G., Foster, G. R., Weesies, G., Mccool, D. \& Yoder, D., 1997. Predicting soil erosion by water: a guide to conservation planning with the Revised Universal Soil Loss Equation (RUSLE), United States Department of Agriculture Washington, DC.

Schmidt, J., Werner, M., Michael, A., 1999. Application of the EROSION 3D model to the CATSOP watershed, The Netherlands. Catena, 37, 449-456. https://doi.org/10.1016/S0341-8162(99)00032-6

Shiferaw, A., 2012. Estimating Soil Loss Rates For Soil Conservation Planning in Borena Woreda Of South Wollo Highlands of Ethiopia: The Case from the Legemara Watershed. Ethiopian Journal of Business and Economics (The), 2, 1-34.

Srinivasan, R., Arnold, J., Jones, C., 1998. Hydrologic modelling of the United States with the soil and water assessment tool. International Journal of Water Resources Development, 14, 315-325.

Tesfaye, A., Negatu, W., Brouwer, R., Van Der Zaag, P., 2014. Understanding soil conservation decision of farmers in the Gedeb watershed, Ethiopia. Land Degradation \& Development, 25, 71-79. https://doi.org/10.1002/ldr.2187

Wischmeier, W.H., Smith, D. D., 1978. Predicting rainfall erosion losses-a guide to conservation planning. Predicting rainfall erosion losses-a guide to conservation planning.

Wischmeier, W.H., Smith, D. D., 1965. Predicting rainfallerosion losses from cropland east of the Rocky Mountains: Guide for selection of practices for soil and water conservation, Agricultural Research Service, US Department of Agriculture Washington DC.

Young, R., Onstad, C., Bosch, D., Anderson, W., 1989. AGNPS: A nonpoint-source pollution model for evaluating agricultural watersheds. Journal of soil and water conservation, 44, 168-173. 